\title{
Solubilization of Araxá natural phosphate and decomposition of plant residues by bacterial isolates
}

\author{
Solubilização de fosfato natural de Araxá e decomposição de resíduos \\ de plantas por isolados bacterianos
}

\author{
Mário Viana Paredes Filho*(D), Adriano Bortolotti da Silva² (D), Ligiane Aparecida Florentino² (D)
}

\author{
${ }^{1}$ Universidade do Vale do Sapucaí/UNIVÁS, Departamento de Engenharia, Pouso Alegre, MG, Brasil \\ ¿Universidade José do Rosário Vellano/UNIFENAS, Departamento de Agronomia, Alfenas, MG, Brasil \\ *Corresponding author: mariomecanica@outlook.com \\ Received in April 3, 2020 and approved in June 26, 2020
}

\begin{abstract}
Brazil imports most of the phosphate fertilizers used in agriculture, however, it has national deposits in its territory that can supply part of the domestic market demand. In order of these to be used effectively, it is necessary to identify techniques to accelerate the release of phosphorus $(P)$ from these rocks. The objective was to evaluate the influence of inoculation with phosphate solubilizing bacterial isolates (PSB) and decomposition of different plant residues in the solubilization of Araxá natural phosphate (ANP). Two experiments were carried out in a completely randomized design in a $5 \times 4$ factorial scheme, with four replicates. The first experiment evaluated the solubilization of ANP by PSB in culture medium with four different sources of carbon: glucose, saccharose, cellulose, and pectin. The treatments were incubated for seven days and then were analyzed the P concentration and $\mathrm{pH}$ values. In the second experiment, the ANP was applied in $300 \mathrm{~cm}^{3}$ of soil, placed in incubation chambers, with six grams of dry and crushed plant material of white oat, brachiaria, crotalaria, lupine, and the inoculation of PSB. Decomposition was evaluated weekly by quantifying the carbon of the $\mathrm{CO}_{2}-\mathrm{C}$ released and, after 42 days was analyzed the concentration of $P$ in the soil. It was observed that the carbon source directly influences the solubilization of ANP by PSB, especially the genus Burkholderia. Treatments containing crotalaria and lupine residues showed higher $\mathrm{CO}_{2}-\mathrm{C}$ values, and the ones containing plant residues associated with BSF inoculation obtained the highest levels of $\mathrm{P}$ in the soil.
\end{abstract}

Index terms: Diazotrophic bacteria; organic material; phosphorus availability in soil; soil microorganisms.

\begin{abstract}
RESUMO
O Brasil importa a maioria de fertilizantes fosfatados utilizados na agricultura, no entanto, possui em seu território jazidas nacionais que podem suprir parte da demanda do mercado interno. Para que estas possam ser utilizadas de forma efetiva, é necessário identificar técnicas para acelerar a liberação de fósforo $(P)$ destas rochas. Com isso, objetivou-se avaliar a influência da inoculação com estirpes bacterianas solubilizadoras de fosfato (BSF) e decomposição de diferentes resíduos vegetais na solubilização de fosfato natural de Araxá (FNA). Foram realizados dois experimentos em delineamento inteiramente casualizado em esquema fatorial $5 \times 4$, com quatro repetições. No primeiro foi avaliado a solubilização de FNA por BSF em meio de cultura contendo quatro diferentes fontes de carbono, glicose, sacarose, celulose e pectina. Os tratamentos foram incubados por sete dias e analisou-se a concentração de $\mathrm{P}$ e o valor de $\mathrm{pH}$. No segundo, o FNA foi aplicado em 300 cm $^{3}$ no solo, disposto em câmaras de incubação e adicionados seis gramas de material vegetal seco e triturado de aveia branca, brachiaria, crotalária e tremoço e inoculação das BSF. A decomposição foi avaliada semanalmente pela quantificação do carbono do CO $\left(\mathrm{CO}_{2}-\mathrm{C}\right)$ liberado e, aos 42 dias, foi analisado a concentração de P no solo. A fonte de carbono influencia diretamente na solubilização do FNA pelas BSF, destacando-se o gênero Burkholderia. Os tratamentos contendo resíduos de crotalária e tremoço apresentaram maiores valores de $\mathrm{CO}_{2}$-C liberado. Os maiores teores de $\mathrm{P}$ no solo foram verificados nos tratamentos contendo resíduos vegetais associado à inoculação BSF.
\end{abstract}

Termos para indexação: Bactérias diazotróficas; material orgânico; disponibilidade fósforo no solo; microrganismos do solo.

\section{INTRODUCTION}

Phosphorus is one of the elements that most limits plant production, since it participates in biochemical molecules, such as ATP (adenosine triphosphate), responsible for the energy in the cell and the DNA and
RNA molecules, being essential for plant development (Marschner, 1995). Considering the characteristics of tropical soils, weathered and with low fertility, the need for phosphate fertilization is justified to obtain satisfactory agricultural production (Saldanha et al., 2017). Also, phosphorus forms bonds with elements of 
the clay fraction, reducing its availability to the plant and, consequently, increasing the frequency of the demand for phosphate fertilizers (Fink et al., 2016).

In Brazilian agriculture, it is estimated that around $55 \%$ of the phosphate fertilizers used are imported (Oliveira; Malagolli; Cella, 2019; Schueler; Dourado; Rizzo, 2019). This fact has attracted the attention of government agencies and researchers, who, in recent years, have been looking for mechanisms and technologies to reduce the dependence on international markets, using national deposits. However, the availability of phosphorus is lower and slower in these rocks when compared to those used in the manufacture of imported phosphate fertilizers (Schueler; Dourado; Rizzo, 2019), limiting its use in agriculture.

In recent years, studies have shown that soil microorganisms, through the production of organic acids, can accelerate the release of nutrients from these rocks, increasing availability in the soil solution for plant absorption (Moreira; Siqueira, 2006). Several studies have emphasized the selection of phosphate solubilizing microorganisms (Massenssini et al., 2016; Schueler; Dourado; Rizzo, 2019; Terra et al., 2019), and presented promising data on the potential for application in the field (Dabaja et al., 2019; Souza et al., 2017; Terra et al., 2019). Thus, these microorganisms are biotechnological alternatives that can enable the use of natural phosphate from national deposits, such as Araxá and Catalão natural phosphate.

However, it must be considered that in the soil, other processes, as decomposition of organic matter, the release of organic acids, also contribute to increasing the availability of nutrients for plants, mainly phosphorus (Pavinato; Rosolem, 2008; Pinheiro et al., 2013). For phosphorus to be solubilized in the soil by organic acids, relatively high concentrations of these compounds are required (Oburger; Jones; Wenzel, 2011), with the organic acid class directly influencing phosphorus adsorption in the soil (Andrade et al., 2003).

It can be assumed that the addition of microorganisms that have a proven ability to solubilize phosphate and organic matter can contribute effectively to increase the release of phosphorus from rock dust. However, it must be considered that this effect can vary according to the microorganism and the residue of available organic matter. Therefore, the objectives of the study were to evaluate the solubilization of Araxá natural phosphate and decomposition of different plant residues by bacterial isolates.

\section{MATERIAL AND METHODS}

\section{Phosphorus solubilization under in vitro conditions}

To evaluate phosphorus solubilization was selected four diazotrophic bacterial strains, two from the Embrapa collection, Ab-V5 (Azospirillum brasilense), and BR 2003 (Bradyrhizobium elkanii), and two isolated from rhizospheric soils of Brachiaria brizantha, UNIFENAS 100-13 (Burkholderia cenocepacia) and UNIFENAS 10039 (B. cenocepacia). These strains were evaluated for their potential to act as promoters of plant growth by Andrade et al. (2019), Terra et al. (2019).

The bacterial strains were evaluated for their ability to solubilize phosphorus from the natural phosphate of Araxá $\left(5 \% \mathrm{P}_{2} \mathrm{O}_{5}\right.$ soluble in citric acid), in culture medium with four different carbon sources (glucose, sucrose, cellulose, and pectin). The statistical design used was completely randomized in a $5 \times 4$ factorial scheme, with the four strains plus a control treatment (without inoculation) and four carbon sources.

All bacterial strains were cultured in a Petri dish containing the FAM medium, with the following chemical composition: $5 \mathrm{~g}$ Saccharose, $0.03 \mathrm{~g} \mathrm{~K}_{2} \mathrm{HPO}_{4}, 0.12 \mathrm{~g} \mathrm{KH}_{2} \mathrm{PO}_{4}$, $0.2 \mathrm{~g} \mathrm{MgSO}_{4} .7 \mathrm{H}_{2} \mathrm{O}, 0.1 \mathrm{~g} \mathrm{NaCl}, 4.0 \mathrm{~mL}$ FeEDTA $(1,64 \%)$, $1 \mathrm{~mL}$ vitamin solution (10 mg biotin, $20 \mathrm{mg}$ pyridoxine, em $100 \mathrm{~mL}$ sterile distilled water), $2 \mathrm{~mL}$ micronutrients solution ( $0.008 \mathrm{~g} \mathrm{CuSO}_{4} .5 \mathrm{H}_{2} \mathrm{O}, 0.024 \mathrm{~g} \mathrm{ZnSO}_{4} .7 \mathrm{H}_{2} \mathrm{O}, 0.28 \mathrm{~g} \mathrm{H}_{3} \mathrm{BO}_{3}$, $0.2 \mathrm{~g} \mathrm{NaMoO}_{4} \cdot 2 \mathrm{H}_{2} \mathrm{O}, 0.263 \mathrm{~g} \mathrm{MnSO}_{4} \cdot \mathrm{H}_{2} \mathrm{O}$ in $200 \mathrm{~mL}$ of distilled water), $1.75 \mathrm{~g}$ agar and $1000 \mathrm{~mL}$ distilled water and pH 6.0 (Magalhães; Döbereiner, 1984).

Subsequently, isolated colonies were transferred to flasks containing liquid FAM medium and incubated at $28{ }^{\circ} \mathrm{C}$ for three days. Then, $25 \mu \mathrm{L}$ of the suspension of each bacterial strain, containing approximately $10^{8}$ colony forming unity $\left(\mathrm{CFU} \mathrm{mL} \mathrm{mL}^{-1}\right)$, was transferred to 50 $\mathrm{mL}$ of GES liquid medium containing $10 \mathrm{~g}$ glucose, $0.1 \mathrm{~g}$ $\mathrm{KNO}_{3}, 100 \mathrm{~mL}$ soil extract (The filtered supernatant of $1 \mathrm{~kg}$ soil in $1 \mathrm{~L}$ distilled water, autoclaved and left to stand for $48 \mathrm{~h}), 2 \mathrm{~mL} \mathrm{MgSO}$ (10\%), $2 \mathrm{~mL} \mathrm{CaCl}_{2}(1 \%), 1 \mathrm{~mL}$ $\mathrm{NaCl}(10 \%), 2 \mathrm{~mL}$ micronutrients solution (the same used in LO medium), $4 \mathrm{~mL} \mathrm{Fe-EDTA} \mathrm{(1.64 \% ),} \mathrm{and} 15 \mathrm{~g}$ agar (Sylvester-Bradley et al., 1982), modified according to the different carbon sources evaluated (glucose, sucrose, cellulose, and pectin) and added with Araxá natural phosphate $\left(14 \mathrm{~g} \mathrm{~kg}^{-1} \mathrm{P}\right)$. The isolates were incubated for 7 days at $28{ }^{\circ} \mathrm{C}$ on an incubator shaker at $120 \mathrm{rpm}$.

The supernatant was separated by centrifugation $\left(10,000 \mathrm{rpm}, 4{ }^{\circ} \mathrm{C}\right.$ for $\left.10 \mathrm{~min}\right)$, and a $\mathrm{pH}$ meter was used to measure the final $\mathrm{pH}$ value. A spectrophotometer was 
utilized to analyze the concentration of soluble phosphorus (Tedesco et. al., 1995). The $\mathrm{pH}$ and soluble phosphorus data were subjected to analysis of variance using the Sisvar statistical analysis program (Ferreira, 2011), and the treatment averages were compared using the Scott-Knott test at $5 \%$ probability.

\section{Decomposition of organic matter and phosphorus solubilization in the soil}

In the second experiment, the soil used was classified as dystrophic Red Latossol (Oxisol) with a clay texture, collected in the 0 to $20 \mathrm{~cm}$ layer. Subsequently, it was sent to the Soil Fertility Laboratory for analysis of the chemical and physical characterization (Teixeira et al., 2017), presenting the following characteristics: $\mathrm{pH}\left(\mathrm{H}_{2} \mathrm{O}\right)=5.2 ; \mathrm{P}\left(\mathrm{mg} \mathrm{dm}^{-3}\right)$ $=1.1 ; \mathrm{K}\left(\mathrm{mg} \mathrm{dm}^{-3}\right)=41 ; \mathrm{Ca}\left(\mathrm{cmol}_{\mathrm{c}} \mathrm{dm}^{-3}\right)=0.7 ; \mathrm{Mg}\left(\mathrm{cmol}_{\mathrm{c}}\right.$ $\left.\mathrm{dm}^{-3}\right)=0.4 ; \mathrm{Al}\left(\mathrm{cmol}_{\mathrm{c}} \mathrm{dm}^{-3}\right)=0.3 ; \mathrm{H}+\mathrm{Al}\left(\mathrm{cmol}_{\mathrm{c}} \mathrm{dm}^{-3}\right)=$ 5.2; $\mathrm{SB}\left(\mathrm{cmol}_{\mathrm{c}} \mathrm{dm}^{-3}\right)=1.3 ; \mathrm{t}(\mathrm{CEC}$ effective $)\left(\mathrm{cmol}_{\mathrm{c}} \mathrm{dm}^{-3}\right)$ $=1.6 ; \mathrm{T}(\mathrm{CEC}$ potential $)\left(\mathrm{cmol} \mathrm{dm}^{-3}\right)=6.5 ; \mathrm{V}(\%)=20 ; \mathrm{m}$ $(\%)=19$; M.O. $\left(\operatorname{dag~kg}^{-1}\right)=2.4$; Clay $=60 \%$; Silt $=29 \%$ and sand $=11 \%$.

Residues of the following plants were used: white oat (Avena sativa L.), brachiaria (Brachiaria decumbens), crotalaria (Crotalaria spectabilis) and lupine (Lupinus albus), cultivated in the agrostological field of the Agricultural Sciences sector of the José do Rosário Vellano University (UNIFENAS). The aerial part of the plants was collected at the flowering period. The plant material was dried in an oven with forced air circulation at $70^{\circ} \mathrm{C}$ for 72 hours, ground and sieved $(2 \mathrm{~mm})$, and part of the samples was sent for bromatological characterization analysis (Table 1).

Table 1: Bromatological characterization of the plant residues.

\begin{tabular}{lcccr}
\hline $\begin{array}{c}\text { Cover } \\
\text { crops }\end{array}$ & Family & NDF $(\%)^{*}$ & FDA $(\%)^{* *}$ & $\begin{array}{c}\text { Protein } \\
(\%)\end{array}$ \\
\hline White oat & Poaceae & 63.48 & 43.02 & 11.03 \\
Brachiaria & Poaceae & 63.23 & 52.14 & 9.34 \\
Crotalaria & Leguminosae & 57.51 & 40.76 & 13.03 \\
Lupine & Leguminosae & 51.44 & 38.09 & 14.07 \\
\hline
\end{tabular}

${ }^{*}$ neutral detergent fiber ${ }^{* *}$ acid-detergent fiber.

To install the experiment incubation chambers were prepared, as described by Monteiro et al. (2002), using 300 $\mathrm{cm}^{3}$ soil, containing $0.3 \mathrm{~g}$ Araxá natural phosphate, $6 \mathrm{~g}$ of plant material, inoculated with $3 \mathrm{~mL}$ of a suspension of the bacterial strain in the $\log$ phase of growth (with approximately $10^{8}$ cells. $\mathrm{mL}^{-1}$ ), and the humidity was kept at $70 \%$ of field capacity.
The statistical design was the completely randomized design, in a factorial scheme 5 (four plant residues and the control treatment without plant residue) $\mathrm{x} 4$ (inoculation with bacterial strains) and four repetitions.

Flasks containing $10 \mathrm{~mL} 0.25 \mathrm{~mol} \mathrm{~L}^{-1} \mathrm{NaOH}$ were inserted into the incubation chambers. The $\mathrm{CO}_{2}-\mathrm{C}$ evolution analysis were carried out for 60 days, and the measurement was done weekly, removing an aliquot of the $\mathrm{NaOH}$ solution from each incubation chamber, in which $10 \mathrm{~mL} 0.025 \mathrm{~mol}$ $\mathrm{BaCl}_{2}$ was added $\mathrm{L}^{-1}$, followed by 3 drops of an alcoholic solution of phenolphthalein $1 \%$ as an indicator and titration with $\mathrm{HCl} 0.1 \mathrm{moL} \mathrm{L}^{-1}$ until the solution turns from violet to colorless. Additional flasks containing $100 \mathrm{~mL}$ of $0.25 \mathrm{moL}$ $\mathrm{L}^{-1} \mathrm{NaOH}$ were inserted into the incubation chambers after each assessment, and the amount of evolved $\mathrm{CO}_{2}-\mathrm{C}$ was calculated using the following Equation 1, cited in Moreira and Siqueira (2006):

$\mathrm{CO}_{2}(\mathrm{mg} / \mathrm{kg}$ dry soil $)=[(\mathrm{Vo}-\mathrm{V}) \times 1.1 \times 1000] / \mathrm{PSS}$

Where: $\mathrm{Vo}=$ volume of $\mathrm{HCl}$ used to titrate the white $(\mathrm{mL})$; $\mathrm{V}=$ volume of $\mathrm{HCl}$ used to titrate the sample $(\mathrm{mL}) ; 1,1=$ conversion factor $\left(1 \mathrm{~mL} \mathrm{NaOH} 0.05 \mathrm{M}=1.1 \mathrm{mg}\right.$ of $\left.\mathrm{CO}_{2}\right)$; $1000=$ to get results in Kg of dry soil; PSS $=$ Dry soil weight.

The accumulated evolved $\mathrm{CO}_{2}-\mathrm{C}$ was expressed in absolute terms ( $\left.\mathrm{mg} \mathrm{CO}_{2}-\mathrm{C}\right)$, and concerning the amount of added carbon $\left(\mathrm{mg} \mathrm{dm}^{-3} \mathrm{CO}_{2}-\mathrm{C}\right)$. After the evaluation period of the evolved $\mathrm{CO}_{2}-\mathrm{C}$, the soil of the incubation chambers was used to analyze the phosphorus concentration by the resin method.

\section{RESULTS AND DISCUSSION}

\section{Phosphorus solubilization under in vitro conditions}

It is observed that the four bacterial strains increased the availability of phosphorus in the culture medium when compared to the control treatment (without inoculation with bacterial strain). Of the tested strains, B. cenocepacia (UNIFENAS 100-39) showed the best performance when grown on the four different carbon sources, showing greater metabolic versatility.

Among the carbon sources tested, cellulose was the one that promoted the lower release of phosphorus in the culture medium, and the treatments inoculated with strains A. brasilense (Ab-V5) and B. elkanii (BR 2003) presented phosphorus values similar to the control treatment (without inoculation). Strains of B. cenocepacia, UNIFENAS 10039 , followed by UNIFENAS 100-13, promoted the release of phosphorus when grown in a medium containing this carbon source. 
Cellulose is a complex polymer to hydrolyze and not all microorganisms have specific enzymes to perform the process, as reported by Silva Filho and Vidor (2000). Thereby, it is observed that these results are important from a practical point of view since cellulose is one of the main constituents of soil organic matter (Moreira; Siqueira, 2006).

Generally, analyzing the carbon sources, it is observed that strains grown in medium containing simple carbohydrates, glucose, and sucrose, promoted the higher release of phosphorus when compared to cultivation in more complex carbon sources, such as cellulose and pectin (Table 2).

The solubilization of phosphate by microorganisms is related to their ability to produce organic acids, which contribute to the breakdown of chemical bonds between the elements, increasing the release of the nutrient (Silva Filho; Vidor, 2000). According to Barroso and Nahas (2008), the carbon source can influence the production of organic acids and, consequently, the efficiency of the process. Therefore, there is a need for studies aiming at selecting microorganisms according to the culture conditions aiming at greater efficiency (Mendes et al., 2014).

Analyzing the culture medium $\mathrm{pH}$ results (Table 2), it appears that the simplest carbohydrates sources promoted a greater reduction of this parameter, which may be related to the production of organic acids (Terra et al., 2019).

Papagianni (2007) reports that the production of organic acids can also contribute to the release of other elements, mainly micronutrients present in the rocks, justifying the importance of using rock dust or rock to obtain sustainable agriculture (Brito et al., 2019).

According to the results, the strains of Burkholderia, UNIFENAS 100-13 and UNIFENAS 100-39 (Table 2) showed greater efficiency in phosphate solubilization, corroborating the data obtained by You et al. (2020), where they verified that $B$. cenocepacia isolates have specific genes involved in the production of gluconic acid, which promotes higher solubilization of inorganic phosphate.

Also, Bolívar-Anillo, Contreras-Zentella and Tehéran-Sierra (2016), report on the potential use of this genus in agriculture for acting in several processes related to plant growth, such as nitrogen fixation, phosphate solubilization, phytopathogen inhibition, production of exopolysaccharides, and siderophores.

Strains UNIFENAS 100-13 and UNIFENAS 10039 also have a proven ability to solubilize potassium and the efficiency of the process varied according to the carbon source (Florentino et al., 2017). In this study, it was possible to observe that the carbon source positively influences phosphorus solubilization, which is directly related to the lowering of the $\mathrm{pH}$ value, as shown in Figure 1.

\section{Decomposition of organic matter and phosphorus solubilization in the soil}

There was no interaction between these parameters and that just the addition of organic residues provided a significant increase in the decomposition of organic matter, given by the accumulated $\mathrm{CO}_{2}-\mathrm{C}$ values (Table 3).

Table 2: Values of soluble phosphorus and $\mathrm{pH}$ in liquid culture medium supplemented with natural phosphate from Araxá and with four different carbon sources, inoculated or not with bacteria isolates, incubated for seven days'.

\begin{tabular}{ccccc}
\hline \multirow{2}{*}{ Treatments } & \multicolumn{4}{c}{ Phosphorus availability $\left(\mathrm{mg} \mathrm{dm}^{-3}\right)$} \\
\cline { 2 - 5 } & Glucose & Saccharose & Cellulose & Pectin \\
\hline Control & $0.09 \mathrm{Ea}$ & $0.08 \mathrm{Ea}$ & $0.07 \mathrm{Ca}$ & $0.08 \mathrm{Da}$ \\
Ab-V5 & $0.48 \mathrm{Da}$ & $0.54 \mathrm{Da}$ & $0.11 \mathrm{Cb}$ & $0.42 \mathrm{Ca}$ \\
BR 2003 & $4.59 \mathrm{Ba}$ & $4.40 \mathrm{Ba}$ & $0.09 \mathrm{Cc}$ & $1.00 \mathrm{Bb}$ \\
UNIFENAS 100-13 & $3.12 \mathrm{Ca}$ & $2.89 \mathrm{Ca}$ & $0.39 \mathrm{Bc}$ & $0.97 \mathrm{Bb}$ \\
UNIFENAS 100-39 & $6.74 \mathrm{Aa}$ & $5.95 \mathrm{Ab}$ & $0.96 \mathrm{Ac}$ & $1.81 \mathrm{Ab}$ \\
\hline & & & $\mathrm{pH}$ & \\
\hline Control & $6.65 \mathrm{Aa}$ & $6.70 \mathrm{Aa}$ & $6.75 \mathrm{Aa}$ & $6.74 \mathrm{Aa}$ \\
Ab-V5 & $6.21 \mathrm{Bb}$ & $6.50 \mathrm{Aa}$ & $6.68 \mathrm{Aa}$ & $6.68 \mathrm{Aa}$ \\
BR 2003 & $5.15 \mathrm{Db}$ & $5.11 \mathrm{Cb}$ & $6.13 \mathrm{Ba}$ & $5.93 \mathrm{Ca}$ \\
UNIFENAS 100-13 & $5.58 \mathrm{Cb}$ & $5.46 \mathrm{Bb}$ & $6.25 \mathrm{Ba}$ & $6.22 \mathrm{Ba}$ \\
UNIFENAS 100-39 & $4.76 \mathrm{Ec}$ & $4.74 \mathrm{Dc}$ & $5.40 \mathrm{Cb}$ & $6.01 \mathrm{Ca}$
\end{tabular}

${ }^{1}$ Means followed by different letters, uppercase in the column and lowercase in the row, for each variable, differ by the Scott Knott test at $5 \%$ probability. 

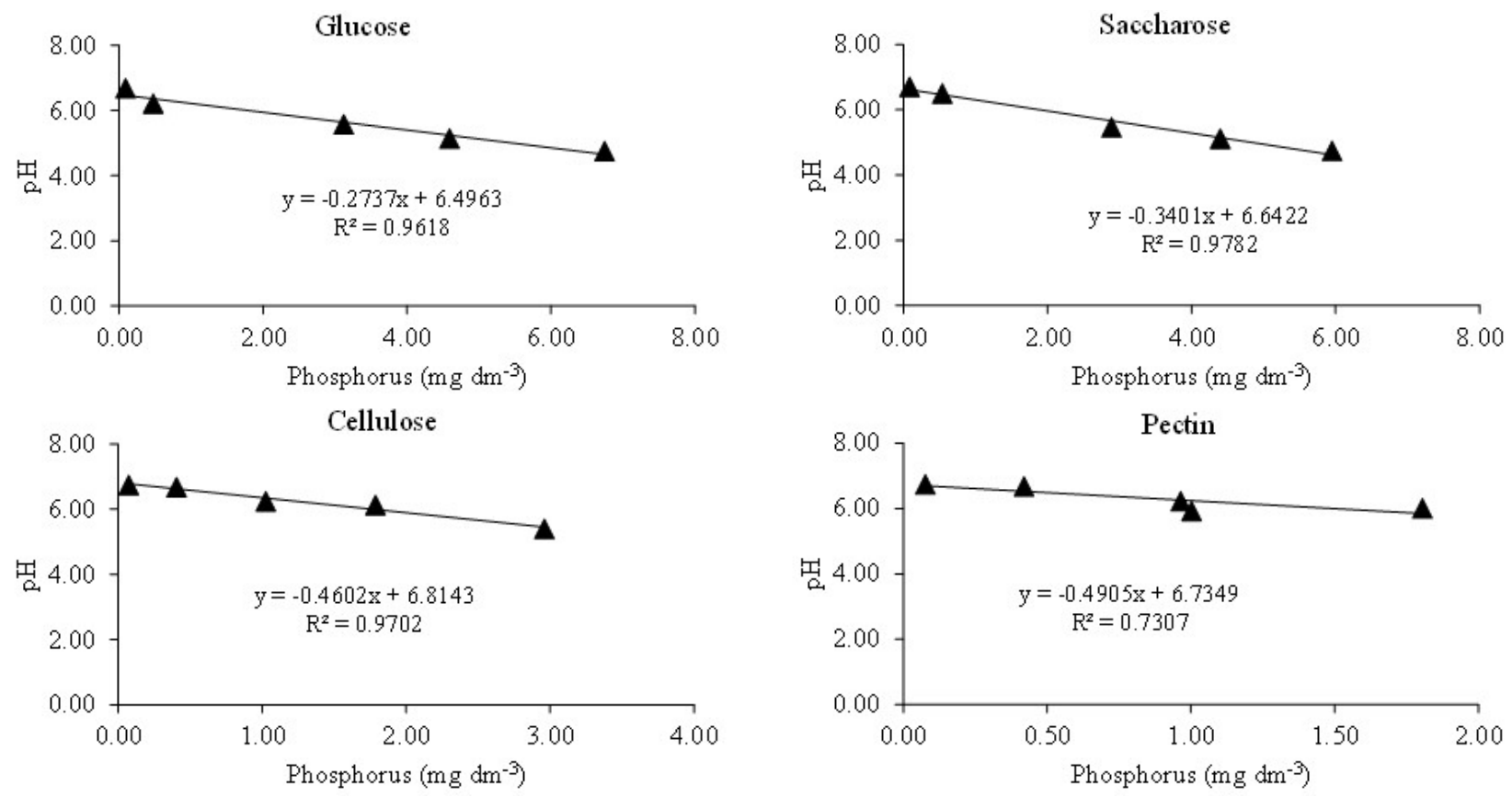

Figure 1: Phosphorus concentration $\left(\mathrm{mg} \mathrm{dm}^{-3}\right)$ and $\mathrm{pH}$ values in culture medium supplemented with natural Araxá phosphate grown with bacterial strains in different carbon sources. ${ }^{*}=p<0,05$.

Table 3: $\mathrm{CO}_{2}-\mathrm{C}$ accumulation in soil containing different cover crops ${ }^{1}$.

\begin{tabular}{cc}
\hline Cover crops & $\mathrm{CO}_{2}-\mathrm{C}$ accumulated $\left(\mathrm{mg} \mathrm{dm}^{-3}\right)$ \\
\hline White oat & $69.43 \mathrm{~b}$ \\
Brachiaria & $67.28 \mathrm{~b}$ \\
Crotalaria & $100.56 \mathrm{a}$ \\
Lupine & $94.38 \mathrm{a}$ \\
\hline
\end{tabular}

${ }^{1}$ Means followed by different letters in the column, differ by the Scott Knott test at 5\% probability.

The two legumes (crotalaria and lupine) showed a higher evolution of $\mathrm{CO}_{2}-\mathrm{C}$, which can be explained by the bromatological characteristics of these plants (Table 1), presenting a higher protein content, which may justify the greater rate of decomposition, estimated by the evolution of $\mathrm{CO}_{2}-\mathrm{C}$.

According to Santos and Meurer (2018), legumes, due to their lower $\mathrm{C} / \mathrm{N}$ ratio, have a higher rate of decomposition and mineralization and, consequently, a greater release of nutrients for plants. Grasses or Poaceae, on the other hand, have greater persistence in the soil (Marangoni et al., 2017), and are also a desirable characteristic of soil quality.

The $\mathrm{CO}_{2}$-C evolution values of the weekly evaluations, resulting from the decomposition rate of the different cover plants present in the soil samples containing Araxá natural phosphate (Figure 2).

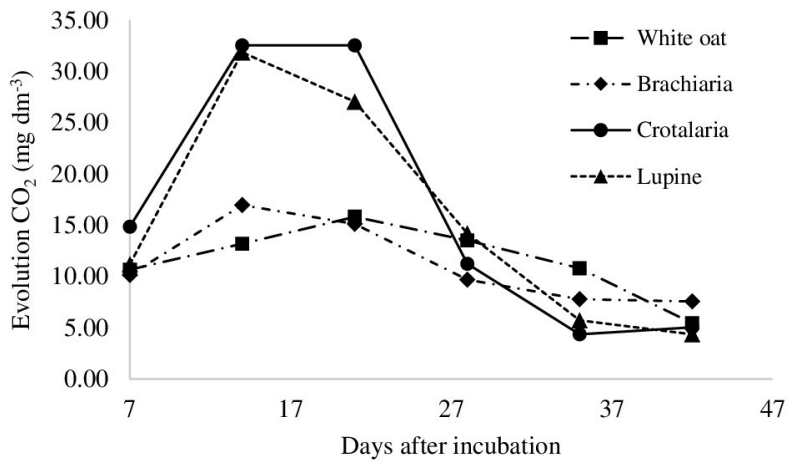

Figure 2: $\mathrm{CO}_{2}-\mathrm{C}$ evolution of soil samples containing natural phosphate from Araxá and different cover crops.

It is observed that crotalaria and lupine residues contributed to the highest $\mathrm{CO}_{2}-\mathrm{C}$ values during the first three weeks, showing that the characteristics of organic waste constitute one of the regulating factors of the decomposition constant (Ramos et al., 2018).

Phosphorus concentration after six weeks of incubation was influenced by the presence of the cover crops and inoculation with the bacterial strains (Table 4). The association between cover plants and bacterial strains influences on the release of phosphorus from the Araxá natural phosphate, with emphasis on white 
Table 4: Values of soluble phosphorus $\left(\mathrm{mg} \mathrm{dm}^{-3}\right)$ in soil samples containing natural phosphate from Araxá, different cover plants, and inoculation with bacterial strains after 42 days of incubation'.

\begin{tabular}{ccccc}
\hline Inoculation/Cover crop & White oat & Brachiaria & Crotalaria & Lupine \\
\hline Control & $1.45 \mathrm{Ba}$ & $1.33 \mathrm{Aa}$ & $1.35 \mathrm{Ba}$ & $1.35 \mathrm{Ba}$ \\
Ab-V5 & $1.80 \mathrm{Aa}$ & $1.43 \mathrm{Aa}$ & $1.50 \mathrm{Ba}$ & $1.63 \mathrm{Ba}$ \\
BR 2003 & $2.03 \mathrm{Aa}$ & $1.45 \mathrm{Ab}$ & $1.55 \mathrm{Bb}$ & $2.10 \mathrm{Aa}$ \\
UNIFENAS 100-13 & $1.48 \mathrm{Ba}$ & $1.35 \mathrm{Aa}$ & $1.40 \mathrm{Ba}$ & $1.55 \mathrm{Ba}$ \\
UNIFENAS 100-39 & $1.95 \mathrm{Aa}$ & $1.50 \mathrm{Ab}$ & $2.13 \mathrm{Aa}$ & $2.15 \mathrm{Aa}$ \\
\hline
\end{tabular}

${ }^{1}$ Means followed by different letters, uppercase in the column and lowercase in the row, for each variable, differ by the Scott Knott test at $5 \%$ probability.

oat inoculated with Ab-V5, BR 2003, and UNIFENAS 100-39; crotalaria associated with inoculation with UNIFENAS 100-39, and lupine inoculated with BR 2003 and UNIFENAS 100-39, which showed about $35 \%$ of efficiency in phosphorus solubilization when compared to the control treatment. Vegetable residues of brachiaria did not influence phosphorus release when associated with bacterial strains inoculation.

It should also be considered that the experiment was evaluated for 42 days and that the $P$ value available in the soil may increase over time, therefore requiring further research.

These results may be due to the action of organic acids released during the decomposition process combined with the performance of soil microorganisms (Pavinato; Rosolem, 2008), enabling the use of national rocks, showing relevance from an economic and environmental point of view.

\section{CONCLUSIONS}

In vitro, phosphate solubilization is influenced by different carbon sources, especially strain 100-39, Burkholderia cenocepacia, which showed greater efficiency. In soil, the highest availability of phosphorus was observed in treatments with white oat and BR 2003, and crotalaria and lupine associated with the 100-39, showing the presence of synergism between organic matter and inoculation with phosphate solubilizing bacterial strains.

\section{ACKNOWLEDGMENTS}

The author thank the Coordination for the Improvement of Higher Education Personnel (CAPES) for the PROSUP scholarship.

\section{REFERENCES}

ANDRADE, F. V. et al. Adição de ácidos orgânicos e húmicos em latossolos e adsorção de fosfato. Revista Brasileira de Ciência do Solo, 27(6):1003-1012, 2003.
ANDRADE, F. M. et al. Beneficial effects of inoculation of growth-promoting bacteria in strawberry. Microbiological Research, 223(1):120-128, 2019.

BARROSO, C. B.; NAHAS, E. Solubilização de fosfato de ferro em meio de cultura. Pesquisa Agropecuária Brasileira, 43(4):529-535, 2008.

BOLÍVAR-ANILLO, H. J.; CONTRERAS-ZENTELLA, M. L.; TEHÉRANSIERRA, L. G. Burkholderia tropica una bacteria con gran potencial para uso en la agricultura. Revista Especializada en Ciencias Químico-Biológicas, 19(2):102-108, 2016.

BRITO, R. S. et al. Rochagem na agricultura: Importância e vantagens para adubação suplementar. South American Journal of Basic Education, Technical and Technological, 6(1):528-540, 2019.

DABAJA, M. Z. et al. Avaliação da atividade enzimática de fungo endofítico isolado de Annona crassiflora (marolo) com interesse biotecnológico. Revista da Universidade Vale do Rio Verde, 17(1):1-10, 2019.

FERREIRA, D. F. Sisvar: A computer statistical analysis system. Ciência e Agrotecnologia, 35(6):1039-1042, 2011.

FINK, J. R. et al. Iron oxides and organic matter on soil phosphorus availability. Ciência e Agrotecnologia, 40(4):369-379, 2016.

FLORENTINO, L. A. et al. Potassium solubilization in phonolite rock by diazotrophic bacteria. Comunicata Scientiae, 8(1):17-23, 2017.

MAGALHÃES, F. M. M.; DÖBEREINER, J. Occurrence of Azospirillum amazonense in some Amazonian (Brazil) ecosystems. Revista de Microbiologia, 15(4):246-252, 1984.

MARANGONI, R. E. et al. Produção de fitomassa seca de guandu-anão e milheto e a decomposição das palhadas sob cultivo do feijoeiro. Revista Agro@mbiente, 11(2):119127, 2017. 
MARSCHNER, $\mathrm{H}$. Mineral nutrition of higher plants. 2. ed. London: Academic Press, 1995. 889p.

MASSENSSINI, A. M. et al. Isolamento e caracterização de bactérias solubilizadoras de fosfato da rizosfera de Eucalyptus sp. Revista Árvore, 40(1):125-134, 2016.

MENDES, G. O. et al. Mechanisms of phosphate solubilization by fungal isolates when exposed to different $P$ sources. Annals of Microbiology, 64(1):239-249, 2014.

MONTEIRO, H. C. F. et al. Dinâmica de decomposição e mineralização de nitrogênio em função da qualidade de resíduos de gramíneas e leguminosas forrageiras. Revista Brasileira de Zootecnia, 31(3):1092-1102, 2002.

MOREIRA, F. M. de S.; SIQUEIRA, J. O. Microbiologia e bioquímica do solo. 2. ed. atual. e ampl. Lavras: Editora UFLA, 2006. 729p.

OBURGER, E.; JONES, D. L.; WENZEL, W. W. Phosphorus saturation and $\mathrm{pH}$ differentially regulate the efficiency of organic acid anion-mediated P solubilization mechanisms in soil. Plant Soil, 341:363-382, 2011.

OLIVEIRA, M. P.; MALAGOLLI, G. A.; CELLA, D. Mercado de fertilizantes: Dependência de importações do Brasil. Revista Interface Tecnológica, 16(1):489-498, 2019.

PAPAGIANNI, M. Advances in citric acid fermentation by Aspergillus niger: Biochemical aspects, membrane transport and modeling. Biotechnology Advances, 25(3): 244-263, 2007.

PAVINATO, P. S.; ROSOLEM, C. A. Disponibilidade de nutrientes no solo - Decomposição e liberação de compostos orgânicos e resíduos vegetais. Revista Brasileira de Ciência do Solo, 32(3):911-920, 2008.

PINHEIRO, G. L. et al. Ácidos orgânicos de baixa massa molar em solos e materiais orgânicos. Química Nova, 36(3):413$418,2013$.
RAMOS, D. D. et al. Decomposição em diferentes espécies de leguminosas (Fabaceae). Cadernos de Agroecologia, 13(2):1-8, 2018.

SALDANHA, E. C. M. et al. Adubação fosfatada na cultura do milho no nordeste paraense. Revista de Ciências Agroveterinárias, 16(4):441-448, 2017.

SANTOS, B. S. A.; MEURER, N. V. F. Liberação de NPK por leguminosas e gramíneas - Análise comparativa. Revista Pensar, 4(1):20-29, 2018.

SCHUEleR, T. A.; DOURADO, M. L.; RIZZO, A. C. L. Processos biotecnológicos para a solubilização de rochas fosfáticas - O estado da arte. Rio de Janeiro: CETEM/MCTIC, 2019. 45p. il. (Série Tecnologia Mineral, 102).

SILVA FILHO, G. N.; VIDOR, C. Solubilização de fostatos por microrganismos na presença de fontes de carbono. Revista Brasileira de Ciência do Solo, 24(1):311-319, 2000.

SOUZA, R. S. et al. Potencial agronômico de bactérias Endofíticas de Echinodorus scaber rataj (macrophyllus) em plântulas de soja. Ensaios e Ciência: Biológicas, Agrárias e da Saúde, 21(3):187-193, 2017.

SYLVESTER-BRADLEY, R. et al. Levantamento quantitativo de microrganismos solubilizadores de fosfatos na rizosfera de gramíneas e leguminosas forrageiras na Amazônia. Acta Amazônica, 12(1):15-22, 1982.

TEDESCO, M. J. et al. Análises de solo, plantas e outros materiais. 2. ed. Porto Alegre: Departamento de solos da UFRGS, 1995. 174p. (Boletim técnico, 5).

TEIXEIRA, P. C. et al. Manual de métodos de análises de solos. 3. ed. rev. e ampl. Brasília, DF: Embrapa, 2017. 574p.

TERRA, A. B. C. et. al. Physiological characterization of diazotrophic bacteria isolated from Brachiaria brizantha rhizosphere. Revista Caatinga, 32(3):658-666, 2019.

YOU, M. et al. Isolation and characterization of Burkholderia cenocepacia CR318, a phosphate solubilizing bacterium promoting corn growth. Microbiological Research, 233(1):126395, 2020. 